\title{
Reacting to the Lucas Critique: The Keynesians' Replies
}

\author{
Aurélien GOUTSMEDT ${ }^{1}$ \\ Université Paris 1 - Centre d'économie de la Sorbonne (CES) \\ Erich PINZÓN-FUCHS \\ Universidad Nacional de Colombia (FCE) \\ Matthieu RENAULT \\ Universidade de São Paulo (FEA-USP) \\ Francesco SERGI \\ University of the West of England (UWE) Bristol
}

In 1976, Robert Lucas explicitly criticized Keynesian macroeconometric models for their inability to correctly predict the effects of alternative economic policies. Today, most contemporary macroeconomists and some historians of economics consider that the Lucas's critique led forcefully to an immediate disqualification of the Keynesian macroeconometric approach. This narrative is based on the interpretation of the Lucas Critique as a fundamental principle for economic reasoning that was (and still is) logically unquestionable. We consider that this narrative is problematic both in terms of historiography and of the effects that it can have in the field as a way of assigning importance and credit to particular macroeconomists. Indeed, the point of view of the Keynesian economists is missing despite the fact that they were the target of Lucas's paper and that throughout the 1970s and 1980s they produced a fierce reaction against it. In this paper we analyze the reactions by a broad set of authors (that we label as "Keynesians") that disputed the relevance of the critique. In spite of their diversity in methodological, theoretical, and policy issues, these reactions were characterized by their common questioning of the empirical and practical relevance of the Lucas critique.

Keywords: History of macroeconomics; Lucas Critique; Keynesian macroeconometrics; Stagflation

JEL codes: B22; B41; E60; E12

\footnotetext{
${ }^{1}$ Corresponding author: Aurelien.Goutsmedt@univ-paris1.fr. We would like to thank Marcel Boumans and the participants of the conference on the "History of macroeconometric modelling" at Utrecht University, as well as Mickaël Assous, Antoine d'Autume, Michel De Vroey, Pedro Garcia Duarte, Kevin D. Hoover, and two anonymous referees for their valuable comments on preliminary versions of this paper. The usual caveat applies.
} 


\section{Introduction}

In his "Econometric Policy Evaluation: A Critique" Robert Lucas (1976) explicitly criticized Keynesian macroeconometric models for their inability to correctly predict the effects of alternative economic policies (ibid., 20). ${ }^{2}$ His argument against these models, as Lucas himself put it, relied on "a single syllogism":

Given that the structure of an econometric model consists of optimal decision rules of economic agents, and that optimal decision rules vary systematically with changes in the structure of series relevant to the decision maker, it follows that any change in policy will systematically alter the structure of econometric models (ibid., 41).

Therefore, Lucas's criticism would be a matter of logic in which (A) the structure of an econometric model is based on relations that describe the behavior of economic agents; (B) this behavior changes along with changes in the decisions of policy-makers; and (C) the structure of the model also changes along with changes in economic policy. Following the logical construction of his argument, Lucas (1976) drew a prescriptive methodological principle: in order to build models that are reliable for quantitative policy evaluation, modelers should formulate behavioral equations that take into account individuals' responses to changes in policies. In turn, this logically grounded prescriptive principle set the bases for the criticism of the Keynesian models, which, according to Lucas, did not abide by this principle, and therefore conducted to misleading policy evaluations.

Today, most contemporary macroeconomists and some historians of economics interpret the Lucas Critique along the lines of a "syllogism," i.e. as a fundamental principle

\footnotetext{
${ }^{2}$ Lucas (1976, 19, fn.2; 21) explicitly referred to Klein and Goldberger (1955) and Tinbergen (1952), even if his Critique targeted more generally the various models stemming from these works. Hereafter, we characterize this line of work as "Keynesian macroeconometrics," as is common in the historiographical literature.
} 
for economic reasoning that was (and still is) logically unquestionable and that led forcefully to an immediate disqualification of the Keynesian macroeconometric approach. This interpretation is notably endorsed by the standard narrative of the history of macroeconomics, which bestows a key role to the Critique as a pathbreaking innovation that dismissed oldfashion, flawed modeling practices (Mankiw, 1990; Hall, 1996; Woodford, 2003). ${ }^{3}$

We consider that this interpretation is problematic both in terms of historiography and of the effects that this narrative can have in the field as a way of assigning importance and credit to particular macroeconomists. Indeed, the point of view of the Keynesian economists is missing from the standard narrative despite the fact that they were the target of Lucas's paper and that throughout the 1970s and 1980s they produced a fierce reaction. Also, Lucas (1976) argued that his critique was more than just a matter of logic, raising (potentially) other related and far more complex issues. Indeed, the Critique has at least a twofold dimension which stands both on methodological and empirical grounds. While the methodological dimension highlighted a limitation in the Keynesian practice in front of changes in economic policy, ${ }^{4}$ the positive dimension turned the understanding of the 1970 s stagflation and the policies adopted at the time as a key exemplar of the failure of macroeconomics models. Emphasizing this twofold dimension of the Lucas Critique is important to understand the Keynesians' reaction, which disputed the relevance of the Critique along these two different dimensions.

The authors that we label as "Keynesians" and whose reactions we study in this paper are not a homogenous set but present a diversity of visions in their methodological

\footnotetext{
${ }^{3}$ The "standard narrative" is the common depiction of the recent evolution of a discipline produced by its practitioners and adopted by some historians. For a more general description of the standard narrative of the history of macroeconomics, see Duarte and Lima (2012), Hoover (2012), and Sergi (2017).

4 Lucas conceded that macroeconometric models were "well designed" for addressing questions "unrelated to quantitative policy evaluation" such as "short-term forecasting" (ibid.).
} 
approaches and in their positions regarding policy and theoretical issues. Yet, despite this diversity, the Keynesians' reactions were characterized by their common questioning of the empirical and practical relevance of the Lucas Critique. ${ }^{5}$

Indeed, these Keynesians took the Critique to have to pass an empirical test. An older generation a priori denied the Critique but put the burden of the empirical proof on new classical macroeconomists. Among those, we discuss the arguments and positions of Franco Modigliani, James Tobin, and Edmond Malinvaud (section 1). In the meanwhile, the empirical assessment of the Critique was further elaborated by a younger generation of Keynesians, among which we consider Alan Blinder, Olivier Blanchard, Robert Gordon and Stanley Fischer. Instead of putting the burden of the empirical proof on Lucas, these authors actively engaged with the econometric testing of parameters' instability, dismissing the Critique on empirical grounds (section 2). Finally, Robert Solow, together with other Keynesians involved in macroeconometric model building, such as Lawrence R. Klein, Otto Eckstein, and again, Fischer and Gordon, recognized that their models had not performed at their best during the stagflation period. Taking Lucas's argument seriously into account, they asked whether it provided a viable alternative to understand the economic context of the 1970s and finally argued that the Critique was not relevant for this purpose (section 3).

\section{The Lucas Critique in the history of macroeconomics}

\subsection{The widespread interpretation of the Critique}

\footnotetext{
${ }^{5}$ We provide a wide perspective of these reactions by covering as much ground as possible in terms of the number of authors studied. However, the contributions selected here are also the only ones that provided a substantial discussion of the Lucas Critique during this period. This selection was based on our careful scrutiny of all the papers citing Lucas (1976) or mentioning the "Lucas Critique."
} 
Consistently with Lucas's own summary of his argument as a logical principle, the Lucas Critique is often understood as a logical axiom or a fundamental principle for producing consistent policy evaluation.

Lucas argued that models conceived for policy evaluation should necessarily involve a careful description of the changes in the behavior of economic agents as a reaction to changes in economic policy rules. Although this argument is usually associated with the rational expectations hypothesis, it actually has a less technical interpretation: since economic agents take into account government decisions to adjust their behavior, the government should formulate its policy considering people's reactions. This interpretation of the Critique is widespread among macroeconomists and historians.

For instance, in his 1985 Preface to Rational Expectations and Inflation (a collection of his early 1980s works), Thomas Sargent reformulated Lucas's fundamental principle into the idea of "strategic interdependence":

one person's pattern of behaviour depends on the behaviour patterns of those forming his environment. When behaviour patterns of those forming a person's environment change, the individual can usually profit by adjusting his or her own behaviour pattern (Sargent, 2013, xxii).

Sargent (1980) had presented this idea through an example drawn from football (namely, how a change in the offside rule would affect players' behavior) and indicated that:

historical patterns of human behaviour often depend on the rules of the game in which people are participating. Since much human behaviour is purposeful, it makes sense to expect that it will change to take advantage of changes in the rules (ibid., 15).

Sargent endorsed the syllogism underlying the Lucas Critique, resulting in the fundamental principle that individuals adapt their behavior in order "to take advantage of 
changes in the rules." Although it might appear "trivial to football supporters," this principle brings important consequences for macroeconometric modeling as it implies that "the field of macroeconomics must be reconstructed in order to take account of this principle of human behaviour" (ibid.). According to Sargent, macroeconomists who ignored that principle (as the Keynesians allegedly did), built their expertise on fallacious foundations, and caused "devastating results."

Understanding the Lucas Critique as a fundamental principle for economic reasoning is equally current in today's economics. In his entry in the New Palgrave Dictionary of Economics "Lucas Critique," Lars Ljungqvist $(2008,1)$ presents the problem raised by Lucas as a problem of "economic logic." According to Ljungqvist, Lucas criticized "the prevailing approach to quantitative macroeconomic policy evaluation for ignoring this logic [and for] being fundamentally inconsistent with [micro] economic theory" (our emphasis). In this sense, the Critique is considered a matter of internal consistency of the logical structure of a macroeconometric model.

This interpretation is not only widespread in macroeconomics but also in the history of macroeconomics. Michel De Vroey $(2016,166)$, for instance, presents the Critique as an argument concerning internal consistency, and suggests that the "best summary" of Lucas's argument is a "syllogism." Furthermore, in accordance to Sargent's and Ljungqvist's interpretations, De Vroey (ibid.) argues that, for Lucas, Keynesian macroeconometric models were unable to provide sound policy evaluations, because they failed to take into account "the fact that agents change their decisions when faced with a change in the policy regime" (ibid.).

\subsection{The Lucas Critique: A cornerstone in the standard narrative of the history of macroeconomics}


Interpreted as a fundamental principle, the Lucas Critique is supposed to have provided the ultimate argument against Keynesian macroeconomics. Preston Miller, for instance, argues that "the Lucas Critique was fatal and [that after it] new approaches had to be developed" (Miller, 1994, xv). To the followers of this view, the Critique was a point of no return for macroeconomics that created the opportunity for the rise of new classical macroeconomics while disqualifying the Keynesian approach. Robert Hall underlines the "revolutionary" nature of Lucas's argument as well, after his awarding of the Nobel Prize in economics:

The Lucas critique [...] has revolutionized the evaluation of policy, down to the most practical level in central banks and finance ministries. [...] Work on the Phillips Curve has been virtually abandoned, devastated by the theoretical and empirical force of the critique. ${ }^{6}$ (Hall, 1996, 38).

This interpretation corresponds to the standard narrative of the history of macroeconomics which is widespread among macroeconomists. This standard account arises from the interpretation of the Critique as a matter of logic, and thus as a "fatal" argument against the Keynesian macroeconometric practice. In terms of logic, indeed, one cannot argue against Lucas's argument; following this perspective, any reply to the Critique by Keynesian macroeconomists should be disregarded as some desperate (and perhaps intellectually dishonest) attempt to preserve a flawed and degenerative research program.

What this narrative promotes is a rhetorical legitimization of the current standard modeling practices. Indeed, this narrative endorses the current status of macroeconomic modeling in which Lucas (1976) is considered a methodological cornerstone. In his

\footnotetext{
${ }^{6}$ Hall's reference to the "empirical force of the critique" is revealing of a haste in assimilating the logical (or theoretical) strength of the argument with its empirical and practical relevance. The controversy on the latter point, and particularly the fact that empirical evidence was not clear-cut, is precisely the issue that we emphasize through the analysis of the Keynesian replies to the Critique.
} 
emblematic book Interest and Prices, Michael Woodford $(2003,13)$ states that the first basic principle for building consistent macroeconomic models today is "to evaluate alternative monetary policies in a way that avoids the flaw in policy evaluation exercises using traditional Keynesian macroeconometric models stressed by Lucas (1976).”

Challenging the standard narrative on the Lucas Critique is therefore not a simple matter of historical accuracy (i.e. to shed light on the Keynesian responses that have been ignored so far). It serves the purpose of unveiling how the Critique, instead of closing, opened a broader debate. In this sense, Lucas's contribution has been a starting point for the history of macroeconomics, and not an ending point or a "fatal strike" against a whole macroeconomics tradition, and so our assessment provides historical perspective not only to the past debate but also to the ongoing discussion about the relevance and interpretation of the Critique within today's DSGE approach (Sergi, 2018). The Keynesians' reactions to the Critique allow us to unveil and discuss the complexity of Lucas's original argument, which goes far beyond the logical syllogism proposed by the standard narrative.

\subsection{The old Keynesians' replies to the Critique}

The older Keynesian generation (Klein, Modigliani, Tobin, Solow, and Malinvaud) acknowledged that, in principle, Lucas (1976) had pointed out a relevant limitation of their macroeconometric modeling practice-namely, the study of agents' expectations. This is an important point, since the reactions of these Keynesians to the Critique are entangled with their criticism of the rational expectations hypothesis (Tobin, 1981; Solow, 1978). Since Lucas used the rational expectation hypothesis to present his argument, it is not surprising to see some Keynesians criticizing simultaneously the rational expectations hypothesis and the Critique. To them, indeed, this hypothesis was not sufficient or even necessary in some cases to solve the problem highlighted by Lucas. In his interview with Klamer (1984, 125-126), 
Modigliani emphasized he had "no objection of principle" on the idea that individuals can react to changes in policy. However, he claimed that his objection was "not one of principles, but of applications" or one of the "specific implications" of dealing with this fundamental idea [of] using rational expectations" (ibid.).

Yet, the decisive point in the old Keynesians reaction is elsewhere: Keynesians never took for granted the empirical relevance of the Critique. In fact, they regarded Lucas (1976) essentially as a theoretical argument, which was still to be tested for its practical relevance for economic policy, and for its ability to be integrated into macroeconometric modeling.

Old Keynesians actually had an a priori judgment on the relevance of the Critique for their modeling practices. An insightful illustration of this stance is Malinvaud $(1998,335)$, who argued that economic agents consider changes in economic policy only when these affect them directly. Furthermore, Malinvaud insisted that neither Lucas nor the new classical macroeconomists had tried to test the empirical validity of the Critique:

At the time, many macroeconomists, especially [me], were not convinced of the scope of [the Critique], although they recognized the correctness of the remark that inspired it. Indeed the small illustrative models presented by Lucas and others, showed no more than a possibility and were in no way tested as to their empirical validity (Malinvaud, 1997, 21).

The important point here is that, to Malinvaud and the old Keynesians, the burden of the proof of the empirical relevance of the Critique rested on its new classical promoters, and so, the Critique should not be admitted a priori.

For their part, new classical macroeconomists were in agreement with the idea that the Lucas Critique should be assessed on empirical bases, and were willing to accept the burden of the proof. Lucas and Sargent made this point in their polemical piece "After Keynesian Macroeconomics:" 
[there is] a number of theoretical reasons for believing that the parameters identified as structural by the methods which are in current use in macroeconomics are not structural in fact. [...] Yet the question of whether a particular model is structural is an empirical, not a theoretical, one (Lucas and Sargent, 1979, 56, our emphasis). ${ }^{7}$

Besides, to Lucas, new classical macroeconometrics already provided a significant amount of evidence corroborating the empirical relevance of the Critique. ${ }^{8}$ This surprising agreement between Keynesians and New Classicals on "the burden of proof" unveils how misleading it would be to read Lucas's paper as suggesting "a simple syllogism" or a fundamental logical principle.

\section{Econometric investigations of the younger Keynesians and empirical relevance of the}

\section{Lucas Critique}

In contrast to the older generation, a younger generation of Keynesians did not hesitate to assume the burden of testing the empirical relevance of the Critique. This younger generation of Keynesians used empirical methods to establish the cases when the Lucas Critique was valid and necessary for economic analysis and when it was not. More precisely, young Keynesians ran econometric tests on the reduced-form relations of their models, and searched for structural breaks and parameters instability after a change in policy rules. The empirical analysis of the Phillips curve- - which was crucial in Keynesian models for discussing the role

\footnotetext{
${ }^{7}$ The same argument can be found in Lucas (1981, 11-12).

${ }^{8}$ Among others, Lucas (1973b), Sargent and Wallace (1973); Sargent (1976), Barro (1977), and Anderson $(1978,1979)$. However, these works are indirect tests of the Critique: they rather focus on the empirical testing of assumptions and predictions related to the Critique (rational expectations, natural rate hypothesis, etc.). Overall, as the rest of the paper shows, Lucas's claim is controversial, and no clear-cut evidence of its relevance emerges, even from the point of view of new classical macroeconometrics (see Sergi, 2015).
} 
of fiscal and monetary policies—-played a central role in these tests. ${ }^{9}$ The simple question that Keynesians were willing to address was whether actual changes in policy (such as the alleged inflationary monetary and fiscal policies of the 1960s, or the "Volcker experience" in 1979) had truly led to a change in estimated relations of Keynesian models — as suggested by Lucas.

To our knowledge, the first Keynesian empirical replies to the Critique appeared only at the end of the 1970s with the publication of Blinder (1979), although Lucas's paper had been well-known and discussed in academia since 1973 (Goutsmedt et al., 2015, 15-16). ${ }^{10}$ This late reaction may be explained by the fact that Lucas's argument seemed to be getting detached from Lucas's original paper. In the specific context of the U.S. stagflation, the Critique progressively gained influence in the public debate. It had been discussed at the U.S. House of Representatives on February 22, 1977, and two articles reporting on this issue had been published in The Wall Street Journal on April and June 1977 (Lucas, Archives, Box 3, Folder 1977 2/2). ${ }^{11}$ In this sense, the Keynesian replies seem to have arisen as the enlarged audience of the Critique started to challenge Keynesians' influence on policy debates. In addition, Paul Volcker's appointment as chairman of the Fed in August 1979 brought an important change in monetary policy, consisting on the tightening of monetary policy and the switch to public money supply targeting. This change created an opportunity to debate both the efficiency of disinflationary policy and the empirical relevance of the Critique.

\footnotetext{
${ }^{9}$ Note that focusing on structural breaks in the Phillips curve only is a narrow enterprise compared to the global perspective developed by Lucas (1976). Indeed, in Lucas's paper, the explicit discussion of the output-inflation trade-off was presented in section 5.3 and only as one illustration (together with the consumption function and investment behavior) of his general argument. The Keynesian focus on the Phillips curve is perhaps related to the crucial role of the curve in other works by Lucas (1972a, 1972b, 1973b) and in his joint paper with Sargent (1979).

10 Of course, Gordon (1976) was the first to reply to Lucas's article in 1973, as he was his discussant in the Carnegie-Rochester Conferences. Even if he exposed some ways to handle the problem raised by Lucas (for instance by estimating parameter shifts with change in economic policy parameters), he did not bring any empirical test, as those developed after Blinder (1979).

${ }^{11}$ For further details on this episode see Goutsmedt et al. (2018).
} 
Keynesians' replies rested on their common view of macroeconometric modeling —of their methodology and practices - a pragmatic view which was deeply rooted in the macroeconometric approach developed by Klein at the Cowles Commission in the 1940s and that dominated the way of doing macroeconomics in the United States until the 1970s (see Bodkin et al., 1991; Acosta and Pinzón-Fuchs, 2018). In this view, macroeconometric modeling was conceived as a practice driven by econometric work that addressed concrete economic questions within a specific context, and that provided daily expertise in matters of economic policy. Therefore, the Keynesian replies to the Critique focused on the econometric analysis of parameters' stability of particular relations at particular periods. This line of work resulted in the rejection of the Critique and its implications for macroeconometric modeling, because it did not seem to provide empirically relevant evidence to explain stagflation, evaluate disinflationary policies, or put into question the Phillips Curve. ${ }^{12}$

This position is well represented by Blinder $(1983,14-15)$ who acknowledged that the "criticisms of the old econometrics made by Lucas, Sargent and others are not wrong; they are absolutely correct." Yet, "it may not always be of great empirical importance." To Blinder, "the critique should take its place as one among many serious problems that confront the applied econometrician" together "with violations of the assumptions of the GaussMarkov theorem," which have "not stopped applied econometrics in its tracks (though it has given cause for humility)":

Perhaps the Lucas critique should be treated in the same way. This broader perspective dictates that we follow a more pragmatic, case by case, approach in

\footnotetext{
12 Lucas's implicit explanation of stagflation, rooted in the Critique argument, could be extrapolated as follows: due to a more inflationary monetary policy, private agents change their expectations about future prices. As they expect higher prices (and wages) in the future, agents substitute current income with leisure, thus decrease their current labor supply. This leads to a simultaneous rise in inflation and a decrease in output.
} 
which we recognize that other problems may be more important than the Lucas critique in particular cases (Blinder, 1983, 14-15).

In addition, as Lucas himself recognized (Lucas, 1976, 20, fn.2), the problem of structural change in macroeconometric models had already been addressed by the "founding fathers" of econometrics, especially by Trygve Haavelmo (1944, 27), Jan Tinbergen (1956, Chap. 5), and Jacob Marschak (1953, 8, 25). These early econometricians had tackled this problem from a pragmatic and empirical perspective, considering it relevant for econometric policy evaluation in particular cases (Goutsmedt et al., 2015, 10-13). In this sense, the replies that the Keynesians made the 1970s and 1980s inherits this macroeconometric tradition.

\subsection{Blinder on U.S. stagflation}

For Blinder, the stability of the Phillips curve was the central issue to be addressed in response to the Lucas Critique. Indeed, by dismissing the traditional inverse relation between inflation and unemployment, the Critique seemed to offer not only an explanation for the observed disappearance of a stable Phillips curve in the 1970s (the parameters of the Phillips curve have changed), but also of the inability of Keynesian models to foresee this event, and a reason for dismissing Keynesian expertise in economic policy. ${ }^{13}$

However, Blinder refused the idea that this instability of the Phillips curve was the consequence of some change in economic agents' behavior following changes in economic policy. Retrospectively, he argued that the success of the Lucas Critique had been the result of a bad inference according to which economists "put two and two together and jumped like lemmings to the wrong conclusion" (Blinder, 1988, 283). Those economists who saw the rising inflation and the changes in the correlation between inflation and unemployment thought that "the government had adopted a more inflationary policy" (ibid.), leading to an

13 Blinder's argument refers to Lucas and Sargent's (1979) claim that the stagflation period represented an "econometric failure on a grand scale" for Keynesian models, and that misleading predictions inspired inflationary policies (Lucas and Sargent, 1979, 6). 
acceleration of inflation in comparison to previous patterns - what means that the parameters in the Phillips curve changed so that the Lucas Critique would explain this phenomenon. Blinder revolted against that use of the Critique, and claimed that there was no proof whatsoever that the disappearance of the traditional Phillips curve during the 1970s was the consequence of a change in the behavior of economic agents who responded to a change in economic policy or in the economic environment. Relying on a simple test of the stability of the Phillips curve ( $c f$. infra), he denounced that the promoters of the Critique did not seek for evidence, but rather "became econometric nihilists. Theory, not data, was supposed to answer [...] questions" (ibid.) about the changes in the behavior of agents in response to policy changes. ${ }^{14}$ Blinder argued that empirical evidence (checking whether changes in the economic behavior of agents had a true and substantial effect on the relation of interest) is the cornerstone of scientific practice, and that the Critique does not abide by this standard.

Likewise, Fischer argued that "the general point made by the critique [was] correct and was known before it was [...] pronounced by Lucas." Yet, "that the point has been important empirically" was "something that should have demonstrated rather than asserted" (Fischer, 1983, 271). Lucas responded to Fischer in a letter expressing his "surprise [...] [regarding Fischer's] statement [since] there [was] a mountain of evidence on this point." (Lucas Archives, Box 5, Folder: 1982 1/2, Lucas to Fischer, 17/11/1981). Fischer dismissed this "mountain of evidence" as just "examples, not empirical demonstrations" (ibid., Fischer to Lucas, 31/12/1981), illustrating that the definition of "empirical evidence" divided the two sides.

\footnotetext{
${ }^{14}$ Blinder had already put forward this lack of empirical evidence in favor of the Critique, in his interview with Klamer:

All you have to do in this country [...] right now is scream mindlessly, "Lucas critique!" and the conversation ends. That is a terrible attitude. The Lucas critique may be correct, but I have seen no persuasive evidence in any sphere to indicate that it is empirically important. The empirical case is yet to be made (Blinder in Klamer, 1984, 166).
} 
These strong statements about the empirical irrelevance of the Critique were the result of several econometric tests. Blinder (1979) was (chronologically) the first to address the Critique by considering a simple empirical Phillips curve: ${ }^{15}$

$$
\dot{p}_{t}=A(L) \dot{p}_{t-1}+f\left(U_{t}\right)+e_{t}
$$

Where $\dot{p}$ represents present $(t)$ and past $(t-1)$ inflation, $A(L)$ are distributed lags, $f\left(U_{t}\right)$ is a function of current unemployment rate, and $e_{t}$ a residual. In this equation, $A(L) p_{t-1}$ should represent a good proxy for the expectation variable $\left.\mathrm{E}_{\mathrm{t}-1 \mathrm{t}} \mathrm{t}\right)$. Let's suppose an increase in the mean level of inflation. If the estimated equation with $A(L) p_{t-1}$ as a proxy continues to fit the data, this means that, despite the change in their environment, there was no fundamental change in the way agents formed their expectations. In his 1988 version of this test, Blinder estimated several simple autoregressions for the period 1955:2 to 1987:4, searching for breaks in parameters' values, as possibly predicted by the Critique. Yet, a Fisher test showed no statistically significant changes among or within time samples. Thus, Blinder concluded that "there is no evidence for a shift in the lag coefficients $A(L)$ " (Blinder, 1988, 283), which he considered a direct empirical evidence against the Critique. ${ }^{16}$

\subsection{Blanchard on the Volcker deflation}

The second example of Keynesian empirical investigation on the stability of the Phillips curve is Blanchard's (1984) "The Lucas Critique and the Volcker Deflation.” The "Volcker experience," besides tightening monetary policy, constituted a substantial change in the way of implementing policy, since the Fed decided to use money supply as a target, and to communicate publicly on the targeting process, in October 1979. According to the Lucas

\footnotetext{
15 The following formalization is inspired from Blinder (1988) rather than from the first version of the test (Blinder, 1979, 92).

${ }^{16} \mathrm{He}$ acknowledged that if we split the sample in two (1955:2-1970:4 vs. 1971:1-1987:4), we observe an increase of the parameter, but "not a dramatic one" (ibid.). Yet, he added that adding supply shocks variables made $A(L)$ more stable. This point echoes the argument of Fischer about change in parameters because of misspecification (see Section 3).
} 
Critique, this could have resulted in a drift in behavioral parameters describing the behavior of private agents. Thus, Blanchard tried to assess the effect of this change in monetary policy on the structure of the Phillips curve, and on the term structure of interest rates.

In this sense, Blanchard analyzed these two relations as they were specified and estimated in two large scale macroeconometric models of the 1970s: (1) the Phillips curve of the Data Resources Incorporated (DRI) model (in use at the Congressional Budget Office) and (2) the term structure drawn from the MPS model of the Fed's Board. He then studied how the estimated coefficients of these relations would change after 1978-introducing additional years, one at the time, into the estimation sample. For the Phillips curve, the results showed roughly unchanged values of coefficients through time. Hence, Blanchard's empirical investigation supported the view of the stability of the Phillips curve relation, arguing that he found "little evidence of a direct effect of the policy change on the Phillips curve, at least until 1982," (Blanchard, 1984, 1). Nevertheless, he warned that his findings did not attest for the accuracy of the DRI's Phillips curve per se. Indeed, his findings simply showed that the Lucas Critique was not relevant for the analysis of the Volcker experiment (as the parameters were stable for the period); or, alternatively, that expectations themselves were not an important factor for explaining inflation---disqualifying the relevance of the Critique (ibid. 213-214).

Concerning interest rates, however, Blanchard acknowledged that "expectations appear[ed] to have changed and the term structure [was] very much subject[ed] to the Lucas Critique" (ibid., 214), leaving open the possibility that Lucas's argument could be relevant for analyzing this particular topic. ${ }^{17}$

17 Similar conclusions were reached by Englander and Los (1983) and Taylor (1984). Although Taylor (1984) contradicted Blanchard's results on the Phillips curve, he was inclined to minimize the validity of his own estimation, since it was based on a smaller sample. 


\subsection{Gordon and King on the sacrifice ratio}

A third example of the Keynesian replies to the Lucas Critique is Gordon and King (1982), although the Critique is not the central issue in their paper. Instead, the paper aims at establishing, through VAR models, the value of the sacrifice ratio for the U.S. (i.e., the cost in terms of output gap of a one-point reduction in inflation). But an entire section of this article is also dedicated to dismissing the empirical relevance of the Critique-which is, indeed, crucial for supporting the idea of a positive sacrifice ratio. ${ }^{18}$

Gordon and King's econometric strategy to investigate the relevance of the Critique starts with an attempt to identify any change in the policy regime, which contrasts with Blanchard (1984) and Taylor (1984), who simply assume this change from the beginning. Gordon and King estimated a feedback monetary growth rule and an inflation equation (both for 1954-1980), then tested the estimated rule with Chow's method. The Chow tests indicated a break in 1967:1 for the equations of quarterly M1 growth (Gordon and King, 1982, 406407), but no break for the inflation equation. ${ }^{19}$ These results dismissed the Lucas Critique argument in the estimation of a sacrifice ratio, leaving "no solid reason to think there would be a marked change in the structure of the inflation equation, and thus in the estimated sacrifice ratio" (ibid., 407). Consequently, their further estimation, resulting in a positive sacrifice ratio (4.3), would legitimately illustrate the costly inefficiency of Volcker's policy.

Even if they did not target the Lucas Critique directly, further works on the cost of the disinflation policy that used more recent data, supported Gordon and King's (1982)

\footnotetext{
${ }^{18}$ Following the Critique: if (A) a disinflation policy is put in practice, then (B) agents adapt their behavior (expecting lower prices in the future, they increase their current labor supply), generating a simultaneous fall in inflation and rise in output (so that sacrifice ratio is zero); it follows that $(\mathrm{C})$ if a model does not take into account $(\mathrm{B})$, then the sacrifice ratio associated with $(\mathrm{A})$ is overestimated.

19 This method differs both from Blanchard (1984) and Taylor (1984), where structural breaks were investigated by adding progressively a further year into the estimation sample. Gordon and King considered that Blanchard's and Taylor's method was weak, considering the small size of their sample.
} 
conclusion. Specifically, George Perry (1983), Otto Eckstein (1985), and Benjamin Friedman (1985) empirically showed that the sacrifice ratio during the Volcker-Reagan era was approximately the same as the one estimated in the late $1970 \mathrm{~s}^{20}$

\section{Some Keynesian alternative explanations to the U.S. stagflation}

In the previous section, we presented Keynesian contributions that converged towards a similar conclusion: the change in parameters following a change in economic policy has no empirical pertinence to explain the economic context of the 1970s and the early 1980s. Interestingly, Lucas reacted to the Keynesians' arguments in the aforementioned piece of correspondence with Stanley Fischer in emphasizing the twofold dimension of his Critique and in trying to disentangle the Keynesians' replies:

One question is whether the "parameter invariance" issue I stressed in my critique is a quantitatively serious criticism of standard econometric models and their applicability to policy evaluation. A second question is whether the forecast errors of these models in the 1970s was mainly due to their failure to possess the right kind of parameter invariance (Lucas Archives, Box 5, Folder: 1982 1/2, Lucas to Fischer, 02/06/1982).

This second dimension of the Lucas Critique was not skipped by the Keynesians and in addition to the empirical arguments dismissing the Lucas critique presented in section 2, they showed that it exists better explanations to the stagflation that the one stemming from the Lucas Critique. In the first place, it is worth noting they recognized that their macroeconometric models had not performed at their best during the 1970s. Yet, the

\footnotetext{
${ }^{20}$ However, these results were contentious, especially because they did not provide direct evidence on the empirical relevance of Lucas's argument. McCallum (1984) argued that these tests ignored an underlying assumption in Lucas's argument, namely that policy changes should be credible. Thus, the cost of the disinflation policy could be explained by the fact that agents did not believe the restrictive commitment of the Fed and did not adjust their expectations quickly enough.
} 
Keynesians unanimously rejected parameters' instability as a significant source of this failure. Some of the Keynesians' alternative explanations to address stagflation had in common the introduction of new variables in the existing macroeconometric models in order to take into account the changes in the economic environment. In particular, they plead for a better description of the supply side of the U.S. economy, and for the introduction of supply shocks on energy and raw materials.

In his correspondence with Lucas, Fischer made clear that he considered the Critique as "one possible source" of the "bad" predictions of the econometric models "for the early seventies." However, "there were many other potential sources of errors" such as those caused by "single equation estimation methods [or by] simple misspecification in [structural] equations," and yet "no one that [Fischer] [knew] of ha[d] made the empirical connection between the bad forecasts of the models and [Lucas's] critique."(ibid., Fischer to Lucas, $31 / 12 / 1981)^{21}$

In later works, Fischer returned to what he thought were the most important "other potential sources" to be investigated, and "misspecification in individual equations" came on top of the agenda. According to him, the Phillips curve especially needed to be reformulated by adding an expectational term after Phelps (1967) and Friedman (1968). This reformulation had been known to modelers since the late sixties, and had been integrated to major models (such as the MPS model which integrated it in 1974). ${ }^{22}$ However, this did not prevent from other sources of misspecification, causing the kind of parameters' variability pointed out by the Critique:

${ }^{21}$ To what Lucas argued that the existence of other problems in Keynesian models was in no way evidence against the Critique: "I certainly agree with you that in principle there are many possibilities besides the failure to possess parameter invariance. There are a lot of ways to do economics badly, and I am willing to believe that one can find all of them in these large-scale models." (ibid., Lucas to Fischer, 02/07/1982).

${ }^{22}$ On the history of the Phillips curve and its multiple avatars, see Qin (2011) and Forder (2014). 
The 1973 supply shock also led to an under-prediction of inflation in the major models, but that has nothing to do with the Lucas critique-unless the Lucas critique is reduced to the statement that models are inevitably misspecified (Fischer, 1988, 302).

On this issue, Blinder $(1987,133)$ argued that once expectational variables were added to the Phillips curve equation, as well as "supply shocks," the major models would fit the 1970s data more accurately. Fischer and Blinder considered here the misspecification of the Phillips curve (i.e. omitted expectation and supply shock variables) to be the source of prediction failures. Consequently, the problem had to be solved by adding further relevant variables into the estimated equation to (better) explain the inflation pattern. This contrasts with Lucas's approach that aimed at a complete change in the structure of the estimated equations since, in accordance with his microfoundational program, the variability of some parameters has to be included as a representation of changes in agents' behavior. ${ }^{23}$

Like Fischer and Blinder, Klein was persuaded that the Critique was not relevant to overcome the prediction problems presented by the large-scale models during the stagflation period. In a paper written in 1976, Klein had already showed how these problems could be easily fixed by adding supply shocks to the model. ${ }^{24}$ His argument resulted from simulations of the Wharton model and illustrated that:

[...] given a conventional fiscal shock, [the Wharton model] would generate the usual trade-off relationship, but if given a food or fuel price shock [the model]

\footnotetext{
${ }^{23}$ Lucas's interpretation in the 1970s has become dominant nowadays, as nicely emphasized by Qin $(2013,120)$ : "[time-varying parameter estimates are] no longer associated with the omitted-variable problem. Instead, time-varying parameters are regarded as the structural representation of the changing behavior of agents as they adapt to changing economic reality."

24 "Longevity of Economic Theory," 1976, box 31, Lawrence R. Klein Papers, David M. Rubenstein Rare Book and Manuscript Library, Duke University. Klein did not address the Lucas critique issue in the article.
} 
would generate a situation of rising unemployment and rising inflation (Klein, 1985, 293).

Hence, the neglect of the energy and food sectors constituted the source of underestimation of the inflation rate in the forecasts of the Wharton model. According to Klein, the prediction problem was about to be solved by the end of the 1970s, when macroeconometric models had managed to introduce the energy and agricultural sectors in a satisfactory manner (ibid., 292). Furthermore, this new available feature allowed econometricians to build "an amplified model that was able to handle the inflation problem more realistically by mid-1975, when inflation was still strong" (ibid.). This point brings the debate back to the question on the originating cause of the 1970s stagflation: Was economic policy responsible for inflation, as Lucas argued, or were it oil and food price shocks? According to Klein, relying on the Wharton simulations, "inflation was not policy induced," or at least, it was "certainly not [induced] from the policies that were coming from the neoclassical-Keynesian model." Instead, inflation "was purely exaggerated by the food and oil shocks" (ibid.).

Eckstein $(1978,1983)$ also investigated different potential sources of the 1970s stagflation in the U.S. Similarly, to Klein's work on the Wharton model, Eckstein ran comparative simulations of the DRI model in which he addressed specific scenarios, capturing a major shock to the economic system. Eckstein (1978) suggested seven scenarios or shocks: energy crises, raises in agricultural prices, changes in monetary policy, devaluation of the dollar, price control, price decontrol, and changes in fiscal policies. When trying to reproduce the stagflation phenomenon in 1969-1974 macroeconomic time series, the "energy crisis" scenario, consisting in an increase of oil prices, was the only one to reproduce both observed high inflation and unemployment. These results supported the idea that changes in 
policy rules, resulting in changes in individual behavior, were simply not a pertinent source of stagflation, while supply shocks in energy prices were the most likely source. ${ }^{25}$

Klein's and Eckstein's simulations were actually framed into a broader project, further developed by Klein in his presidential address to the American Economic Association, entitled "The Supply Side" (Klein, 1978). Klein defended the idea that the supply side of the macroeconometric models was underdeveloped and proposed combining them with the "Leontief model of interindustrial flows" (ibid., 1). As Klein explained, retrospectively, until the 1970s "[m]any people failed to realize how important energy or oil, in particular, was for the economy because it represented only a tiny share of total GNP” (Klein, 1985, 290). Henceforth, developing this "supply side" was on the top of his research agenda, and was actually followed by other researchers at the time. ${ }^{26}$

Gordon followed a research path similar to the one advocated by Klein. In a series of articles, he developed an elaborated "triangle" model to explain stagflation (Gordon 1975, 1984). In his framework, inflation was explained in addition to the employment rate by price inertia (a form of adaptive expectations in which inflation yesterday explains inflation today), and supply shocks. Gordon (2011) defends his model still nowadays, showing its capacity to fit the data, and to explain indirectly the failures of the large-scale-model-based predictions of the end of the 1960 s and 1970 s. $^{27}$

In conclusion, it is worth noting that not only these authors but most Keynesians defended the view that the Lucas Critique was not relevant to address stagflation. For them, the true challenge on macroeconometric models given by stagflation was elsewhere. In his

\footnotetext{
${ }^{25}$ After he carried out new tests later on, Eckstein drew a clear general conclusion: "changes in policy regime seem to have been among the minor sources of structural change of the economy and of forecasting error in the actual historical record." (Eckstein, 1983, xi-xii).

26 This was notably the case of Eckstein (1976), who considered that "the most exciting econometric research today is in the fields of energy, capacity planning, food supply" (ibid., 19).

${ }^{27}$ On Gordon's analysis of the Phillips curve in the 1970s see Goutsmedt and Rubin (2018).
} 
conclusive statement to the conference "After the Phillips Curve," held at the Boston Fed in June 1978, Solow suggested indeed - in line with Klein and Eckstein - that the main priority was to improve the macroeconometric models by developing the supply side of the economy, and by carrying on with empirical work on "the side of food, oil, nonfuel minerals, and the depreciation of the dollar" (Solow, 1978, 205).

\section{Concluding Remarks}

In this article, we studied some of the replies that Keynesian macroeconomists gave to the Lucas Critique in the1970s and 1980s. So far, these replies had been either ignored or disqualified by the standard narrative of the history of macroeconomics, which relies on the interpretation of Lucas (1976) as a logical argument that inevitably dismissed Keynesian models. We argued instead that this interpretation misses the main point of the Keynesians' replies, which consisted in questioning the empirical relevance of Lucas's argument to account for the macroeconomic context of the time.

The case of the reception of the Critique serves as an illustration of a general historiographical point. If one took the histories told by macroeconomists today as faithful accounts of the history of the discipline, one would discover a narrative in which the contributions of old Keynesians in the 1970s seem unimportant and so had consequently been erased of the story. Here, we hope to have made the case that, if there was a Keynesian retreat, this was a tactical one. Their empirical work should not be perceived as an attempt to simply preserve the status quo of the discipline, nor should their refusal to take into consideration Lucas's arguments be seen as a kind of theoretical conservatism or ideological bias. The main claim of this paper is that their replies were motivated by the very nature of the Keynesian macroeconometric tradition, which consisted in addressing concrete economic situations with empirical rigor. In this sense, testing econometrically the relevance of Lucas's 
argument was a natural way of approaching the question on a scientific basis. Similarly, neglecting rational expectations as the main point of their research agenda was natural, since empirical evidence indicated that supply shocks accounted as the main factor of the 1970s stagflation. These replies, however, were neither sufficient to take down the Lucas Critique nor to stop the development of new classical macroeconomics, which was perceived by some Keynesians as an illegitimate "palace coup" that lacked an empirical basis.

\section{References}

Acosta, Juan and Erich Pinzón-Fuchs. 2018. "Macroeconometric modeling and the SSRC's Committee on Economic Stability, 1959-1963.” CHOPE Working Paper No. 2018-08, pp. 135.

Anderson, A. 1978. "Rational Expectations: How important for Econometric Policy Analysis?" Federal Reserve Bank of Minneapolis Quarterly Review 2 (4): 4-10.

—. 1979. "Rational Expectations Forecasts for Nonrational Models." Journal of Monetary Economics 5 (1): 67-80.

Barro, R. J. 1977. "Unanticipated Money Growth and Unemployment in the United States." American Economic Review 67 (2): 101-115.

Blanchard, O. J. 1984. "The Lucas Critique and the Volcker Deflation.” American Economic Review 74 (2): 211-215.

Blinder, A. S. 1979. Economic Policy and the Great Stagflation. London: Academic Press.

— 1983. "A Skeptical Note on the New Econometrics." Working Paper 1092, National Bureau of Economic Research.

—. 1987. "Keynes, Lucas, and Scientific Progress." American Economic Review 77 (2): 130-136. 
—. 1988. "The Fall and Rise of Keynesian Economics." Economic Record 64 (4): 278294.

Bodkin, R., L. Klein, and K. Marwah. 1991. A History of Macroeconometric Model-Building. Edward Elgar Publishing.

De Vroey, M. 2016. A History of Modern Macroeconomics from Keynes to Lucas and Beyond. Cambridge: Cambridge University Press.

Duarte, G. P. and G. T. Lima. 2012. Microfoundations Reconsidered. The Relationship of Micro and Macroeconomics in Historical Perspective. Cheltenham: Edward Elgar.

Eckstein, O. 1976. "Econometric Models and the Formation of Business Expectations." Challenge, pages 12-19.

—. 1978. The Great Recession, with a Postscript on Stagflation. Amsterdam: NorthHolland Publishing.

—. 1983. The DRI model of the U.S. Economy. New York (NJ): McGraw-Hill Companies.

—. 1985. "Disinflation." In Issues in Contemporary Macroeconomics and Distribution, edited by G.R. Feiwel, pages 297-323. London: Palgrave Macmillan UK.

Englander, A. S. and C. A. Los. 1983. "The Stability of the Phillips Curve and Its Implications for the 1980s.” Technical Report 8303, Federal Reserve Bank of New York.

Fischer, S. 1983. "Comment on Macroconfusion: The Dilemmas of Economic Policy." In Prices and Quantities: Essays in Memory of Arthur M. Okun, edited by J. Tobin. Brookings Institution Press, Washington, D.C.

—. 1988. "Recent Developments in Macroeconomics." The Economic Journal 98 (391): 294-339.

Forder, J. 2014. Macroeconomics and the Phillips Curve Myth. Oxford: Oxford University Press. 
Friedman, B. 1985. "Recent Perspectives in and on Macroeconomics." In Issues in Contemporary Macroeconomics and Distribution, edited by G.R. Feiwel, pages 270-286. London: Palgrave Macmillan UK.

Friedman, M. 1968. "The Role of Monetary Policy." American Economic Review 58 (1): 117.

Gordon, R. J. 1976. "Can econometric policy evaluations be salvaged?-A comment”. In Carnegie-Rochester Conference Series on Public Policy. 1:47-61.

—.1975. "Alternative Responses of Policy to External Supply Shocks" Brookings Papers on Economic Activity 1975 (1): 183-206.

—. 1984. "Supply Shocks and Monetary Policy Revisited." American Economic Review 74 (2): $38-43$.

—. 2011. "The History of the Phillips Curve: Consensus and Bifurcation." Economica 78 (309): 10-50.

Gordon, R. J. and King, S. R. 1982. "The Output Cost of Disinflation in Traditional and Vector Autoregressive Models.” Brookings Papers on Economic Activity 1982 (1): 205.

Goutsmedt, A., E. Pinzón-Fuchs, M. Renault, and F. Sergi. 2015. "Criticizing the Lucas Critique: Macroeconometricians' Response to Robert Lucas.” Documents de travail du CES 2015.59, Centre d'Economie de la Sorbonne (CES).

Goutsmedt, A., Guizzo, D. and Sergi, F. (2018) An agenda without a plan: Robert E Lucas's trajectory through the public debate. Working Paper. Centre for the History of Political Economy (Duke University), Durham, NC.

Goutsmedt, A. and Rubin, G. 2018. "Robert J. Gordon and the Introduction of the Natural Rate Hypothesis in the Keynesian Framework." History of Economic Ideas (forthcoming). Haavelmo, T. 1944. "The Probability Approach in Econometrics." Econometrica 12 (Supplement): iii-vi + 1-115 . 
Hall, R. E. 1996. "Robert Lucas, Recipient of the 1995 Nobel Memorial Prize in Economics." The Scandinavian Journal of Economics 98 (1): 33-48.

Hoover, K. D. 2012. "Microfoundational programs." In Microfoundations Reconsidered. The Relationship of Micro and Macroeconomics in Historical Perspective, edited by Duarte, G. P. and G. T. Lima, pages 19-61. Cheltenham: Edward Elgar.

Klamer, A. 1984. The New Classical Macroeconomics. Conversations with the New Classical Economists and Opponents. Brighton: Wheatsheaf Books.

Klein, L. R. 1978. “The Supply Side.” American Economic Review 68 (1): 1-7.

— 1985. "Did Mainstream Econometric Models Fail to Anticipate the Inflationary Surge." In Issues in Contemporary Macroeconomics and Distribution, edited by G.R. Feiwel, pages 270-286. London: Palgrave Macmillan UK.

Klein, L. R. and Goldberger, A. S. 1955. An Econometric Model of the United States, 19291952. Amsterdam: North Holland Publishing.

Ljungqvist, L. 2008. “Lucas Critique.” In The New Palgrave Dictionary of Economics, edited by S. N. Durlauf and L. E. Blume. Basingstoke: Palgrave Macmillan.

Lucas, R. E. 1972a. "Econometric Testing of the Natural Rate Hypothesis." In Studies in Business Cycle Theory, edited by R. E. Lucas, pages 90-103. Cambridge, Mass: MIT Press.

—. 1972b. "Expectations and the Neutrality of Money." Journal of Economic Theory 4 (2): $103-124$

—_. 1973a. "Econometric Policy Evaluation: A Critique." Carnegie-Mellon Working Paper, Carnegie-Mellon. May 1973.

—. 1973b. "Some International Evidence on Output-Inflation Tradeoffs." American Economic Review 63 (3): 326-334.

—. 1976. "Econometric Policy Evaluation: A Critique." Carnegie-Rochester Conference Series on Public Policy 1: 19-46. 
—. 1981. Studies in Business-Cycle Theory. Cambridge, Mass: MIT Press.

—. Archives. Robert E. Lucas Papers, 1960-2011 and undated. David M. Rubenstein Rare Book \& Manuscript Library, Duke University, Durham (NC).

Lucas, R. E. and T. J. Sargent. 1979. “After Keynesian Macroeconomics.” Federal Reserve of Minneapolis Quarterly Review 3: 1-6.

—. 1981. Rational Expectations and Econometric Practice. London: George Allen and Unwin Ltd.

Malinvaud, E. 1997. "L'économétrie dans l'élaboration théorique et l'étude des politiques." L'Actualité économique 73 (1-2-3): 11-25.

—. 1998. "La modélisation en macroéconomie appliquée : quarante ans après." Cahiers Economiques de Bruxelles (160): 329-342.

Mankiw, N. G. 1990. “A Quick Refresher Course in Macroeconomics.” Journal of Economic Literature 28 (4): 1645-1660.

Marschak, J. 1953. "Economic Measurement for Policy and Prediction." In Studies in Econometric Method, edited by W. C. Hood and T. G. Koopmans, pages 1_26. New York: Wiley, Cowles Commission Monograph, nr. 14.

McCallum, B. T. 1984. "Credibility and monetary policy.” Technical Report Working Paper No. 1490, National Bureau of Economic Research Cambridge, Mass., USA.

Miller, J. 1994. The Rational Expectations Revolution: Readings from the Front Line. Cambridge, Mass: MIT Press.

Perry, G. L. 1983. "What Have We Learned about Disinflation?” Brookings Papers on Economic Activity 1983 (2): 587-602.

Phelps, E. S. 1967. "Phillips Curves, Expectations of Inflation and Optimal Unemployment over Time.” Economica 34 (135): 254-281. 
Qin, D. 2011. "The Phillips Curve from the Perspective of the History of Econometrics." History of Political Economy 43 (suppl. 1): 283-308.

- 2013. A History of Econometrics: The Reformation from the 1970s. Oxford: Oxford University Press.

Sargent, T. J. 1976. "The Observational Equivalence of Natural and Unnatural Rate Theories of Macroeconomics." Journal of Political Economy 84 (3): 631-640.

—. 1980. "Rational Expectations and the Reconstruction of Macroeconomics." Federal Reserve Bank of Minneapolis Quarterly Review 4 (3): 15-19.

—. 2013. Rational Expectations and Inflation. Princeton (NJ): Princeton University Press.

Sargent, T. J. and Wallace, N. 1973. "Rational Expectations and the Dynamics of Hyperinflation.” International Economic Review 14 (2): 328-350.

Sergi, F. 2015. "Robert Lucas and the Twist of Modeling Methodology. On some Econometric Methods and Problems in New Classical Macroeconomics." Documents de travail du CES 2015.88, Centre d'Economie de la Sorbonne (CES).

— 2017. "The Standard Narrative on History of Macroeconomics: Central Banks and DSGE Models." Communication at the Annual Meeting of the History of Economics Society, Toronto, 22/06/2017.

—. 2018. "The DSGE Models and the Lucas Critique. A Historical Appraisal." Economics Working Paper Series, University of the West of England Bristol.

Solow, R. 1978. "Summary and Evaluation.” In After the Phillips Curve: Persistence of High Inflation and High Unemployment, pages 203-209. Boston: Federal Reserve of Boston, Federal Reserve of Boston Conference Series.

Taylor, J. B. 1984. "Recent Changes in Macro Policy and its Effects: Some Time-Series Evidence.” American Economic Review 74 (2): 206-210. 
Tinbergen, J. 1952. On the Theory of Economic Policy. Amsterdam: North Holland Publishing.

—. 1956. Economic Policy: Principles and Design. Amsterdam: North Holland.

Tobin, J. 1981. "The Monetarist Counter-Revolution Today. An Appraisal.” The Economic Journal 91 (361): 29-42.

Woodford, M. 2003. Interest and Prices: Foundations of a Theory of Monetary Policy. Princeton (NJ): Princeton University Press. 